\title{
Development of methodology for time management of construction projects
}

\section{Развитие методики контроля сроков инвестиционно- строительного проекта}

\author{
S. V. Bovteev, \\ Peter the Great St. Petersburg Polytechnic \\ University, Saint Petersburg, Russia \\ S.V. Kanyukova, \\ Peter the Great St. Petersburg Polytechnic \\ University, Saint Petersburg, Russia
}

\author{
Канд. техн. наук, доцент С. В. Бовтеев, \\ Санкт-Петербургский политехнический \\ университет Петра Великого, Санкт- \\ Петербург, Россия \\ аспирант С. В. Канюкова, \\ Санкт-Петербургский политехнический \\ университет Петра Великого, Санкт- \\ Петербург, Россия
}

Key words: Construction Project Management, Project Time Control, Project Schedule, Schedule Timeliness Index, Schedule Progress Index, Project Catastrophe

\section{Ключевые слова: Управление}

инвестиционно-строительными проектами, Контроль сроков проекта, Расписание проекта, Индекс своевременности проекта, Индекс выполнения проекта, Катастрофра проекта

\begin{abstract}
This article dwells upon the issues of providing project timely completion as well as key project milestones. In many cases project deadline exceed leads to catastrophic outcomes for the aims and results of the project. Thus, the present article deals with the relevant issues of project schedule control, methodology study based on application of Schedule Timeliness Index and Schedule Progress Index, indicating upon reaching the critical value of extreme deviations from the forecast project duration of targeted project implementation at any moment of time. The suggestion herein is to calculate the minimum possible durations for each project activity and estimate the project duration safety margin coefficient. Based on the safety margin coefficient value it is suggested to define the border values for project shift from one status to another upon criteria of its timely completion possibility. The suggested methodology can be recommended for use by construction project managers in order to prevent a potential failure of project completion deadlines. The system indicating critical project time variance enables to initiate the process of project schedule adjustment before point of no return and herewith prevent project failure. The studied methodology was implemented in modern project management software sphere.
\end{abstract}

Аннотация. В статье рассмотрены вопросы обеспечения своевременности завершения проекта, а также ключевых вех проекта. Во многих случаях превышение срока реализации проекта приводит к катастрофическим результатам целей проекта. Настоящая статья посвящена актуальным вопросам управления расписанием проекта, методике исследования, основанной на применении индекса своевременности проекта и индекса выполнения проекта, указывающих достижение критического значения предельных отклонений от прогнозного срока общей продолжительности проекта в любой момент времени осуществления проекта. В настоящей статье предложено рассчитывать минимально возможную продолжительность для каждой работы проекта и оценивать предельный коэффрициент запаса продолжительности проекта. На основе предельного значения коэфффициента запаса предложено определить границы значений для проекта при переходе от одного статуса к другому по критериям возможности его своевременного завершения. Предложенная методика может быть рекомендована для использования руководителями строительными проектов для предотвращения возможного срыва срока завершения проекта. Система может определить наступление критических значений и позволяет инициировать процесс регулирования оставшегося графика выполнения проекта до наступления точки невозврата и тем самым предотвратить срыв всего проекта. Исследуемая методика была также реализована в современном программном обеспечении управления проектами. 


\section{Introduction}

There is a modern tendency in construction projects to pay special attention to completion of works and commissioning of the projects on time. There can be distinguished a number of projects where it is crucial to prevent a failure to meet construction deadlines, e.g. it was necessary to complete all the works and commission the Olympic Projects in Sochi before the start of the Olympic Games, football stadiums are to be completed by the Football World Cup 2018 and the like. Commissioning of such projects later than on the fixed date (deadline) results not only in drastic decrease in project effectiveness but can lead to the total program failure it was a part of. Thus, when working with the crucial projects where deadlines failure is not acceptable it is necessary to pay special attention not only to comprising and optimization of the Construction Project Schedule but also creation of effective system of monitoring, control and management of the project.

The subject of research herein is to study the methods of calendar planning and control over timing of works within the construction project.

The aim of the study is to create and develop a system of activities timing control and monitoring within construction project that can prevent catastrophe due to failure of timely project completion. This article addresses the situations when the project timely completion is the top priority for the project manager and timely completion is the key criteria of the construction project success. Therefore, there is a possibility to increase the project budget within certain limits if it provides correction of negative deviations from the activities deadlines.

\section{Literature review}

In accordance with the generally accepted project management principle, effective schedule management is considered to be the key to successful project completion. Therefore, all main methods of project management emphasize the importance of tasks calendar planning and control over the schedule [1-8].

Project Tracking - regularly performed process of collecting actual data on activities performance, comparing them with the planned parameters and comprising reports on activities performance status. Project Control is understood as a regular collection of actual indicators of project works, comparing them with the planned ones, analysis of the results and taking manager's decisions in order to eliminate negative factors and provide achievement of the target results of the project [9-13].

In Project Management Body of Knowledge (PMBOK® Guide) PMI [14], which is the guideline for most project managers in the World; its principles lie in the basis of such modern software for project management as Microsoft Project, Oracle Primavera, Spider Project, Asta PowerProject. Project planning methods are presented in quite details $[9,15]$, but there is no sufficiently complete information on principles how to achieve the planned targets, first of all based on dates of separate activities and the overall project. The latest revision 5 of PMBOK includes the process of activities dates control - procedure 6.7 "Control Schedule", which prescribes to use Critical Path Method, Critical Chain Method, Earned Value Management and/or Trend Analysis for work performance status reports [14].

Moreover, for schedule control PMBOK prescribes to use Project Management Software, Resource Optimization Technique, Modeling Technique, Leads and Lags, Schedule Compression and Scheduling Tool [14].

Let us consider the main methods among those listed above.

In the 1950s two similar methods for work management within project implementation were developed.

Critical Path Method (CPM) was suggested by companies «DuPont» and «Remington Rend» for the management of big projects on DuPont Plants modernization [16-18].

The basis of the method is to define the longest duration of the networks of tasks from the start until the end of the project with regard to their links. The tasks that lie on the critical path (critical tasks) have zero time reserve and when their duration is changed all project dates are changed too. But this method requires further studies for project schedule control.

Program Evaluation and Review Technique (PERT) was created by Lockheed corporation, consulting company «Booz, Allen and Hamilton Inc» for the USA Navy during development of PolarisSubmarine weapon system. PERT was developed mainly for the reason of simplifying planning and comprising schedules of big and complex projects. PERT is applied to very massive, simultaneous, complex, and unusual projects. The method implies an uncertainty and possibility to develop the project working schedule without precise knowledge of all details and necessary duration of all its composites [16-17, 19-20].

Bovteev S.V., Kanyukova S.V. Development of methodology for time management of construction projects Magazine of Civil Engineering. 2016. No. 2. Pp. 102-112. doi: 10.5862/MCE.62.10 
Critical Chain Project Management (CCPM) was first described in 1997 in Eliyahu M. Goldratt book «Critical Chain» [21], the method was supported by experts as it was very close to classical PERT's method. The method uses the buffers to eliminate project risks and provide balance of the Project schedule, visualizing fever chart, project estimate from its end date not from the start date as it is done in PERT method, which gives an advantage for project control [21-23].

Earned Value Management (EVM) is based on definition of proportion of the actual costs to the planned value of activities which shall be completed by the target date. This method is used world-wide but not very popular in the Russian practice. There are some researches known on applying the earned value technique for control and project dates forecast. However, the earned value management technique uses project cost indicators as basis, while it is rational to use time indicators. The distinctive feature between the cost and time indicators is that the later cannot be summed up, i.e. a project's total duration is not equal to the sum of its activities durations and defined by the duration of the critical path [24-26].

Herein it is demonstrated that in the projects, where cost of critical works makes little value of the Project cost (e.g. critical path includes works on design approval or construction permit), forecast of the overall duration of the project can lead to the wrong result. In such project, where Planned Value of the critical works is comparable with the Planned Value of non-critical path works, Earned Value Management technique can lead to correct results [27].

Project Milestones Method significantly improves project schedule management as it focuses on tracking the most important events (control points) of a project connected as a rule to the achievement of intermediate project results. When the control points are reached, the planned and actual indicators are usually compared as for the moment of the control point. The control point description includes information on when the planned tasks can be completed and what will be the result of their performance $[12,16,18]$.

\section{Setting goals}

The main aim of project time management is to assure project completion on time. Tracking and analysis of project dates, providing data for follow-up control imply comparing basic (approved) parameters of works with actual (for performed tasks) and forecasted (for planned events) parameters. During project implementation process there always appear deviations from the basic schedule parameters, which can cause positive, negative or neutral effect on overall project duration, according to the majority of project management techniques integrated into the project management software.

Oracle Primavera, Microsoft Project, Spider Project and others, the project manager is suggested to organize regular (usually weekly) collection of actual data and preparing a report demonstrating disruption of baseline finish dates, including emphasizing critical works disruption. Such methods provide data for analysis of the status and make management decisions only at tactical level meanwhile achievement of timely construction project completion in whole is a strategic task. Hence, solving this main strategic task the main parameter of control is the deviation of the expected date of project completion $T_{\text {for }}$ for the planned (i.e. prescriptive or approved) completion date $T_{\text {tar: }}$ :

$$
T V=T_{\text {tar }}-T_{\text {for }}
$$

where TV-Time Variance, i.e. variance of the completion date of the project;

$T_{\text {tar }}$ - target completion date of the project (determined upon schedule approval and stays fixed constant within the overall project duration;

$T_{\text {for }}$ - forecast completion date of the project (determined by recalculation of updated schedule upon actual report issue date).

$T V=f(t)$, where $t-$ time of project implementation.

The strategic target to provide timely project completion is achieved in case when:

$$
T V\left(t=T_{\text {tar }}\right) \leq 0
$$

Therefore, it is necessary to suggest the technique of project time control which preserves this identity (2).

To proof the necessity of developing this technique consider the following example.

Consider construction project, which consists of 6 activities: A, B, C, D, E, F. Activities A-B, A-C, B$D, C-E, D-F, E-F$ are connected with the links type "Finish-Start". Durations, set as the given data and dates of Activities' completion calculated with the method of the Critical Path are presented in the Figure 1. 


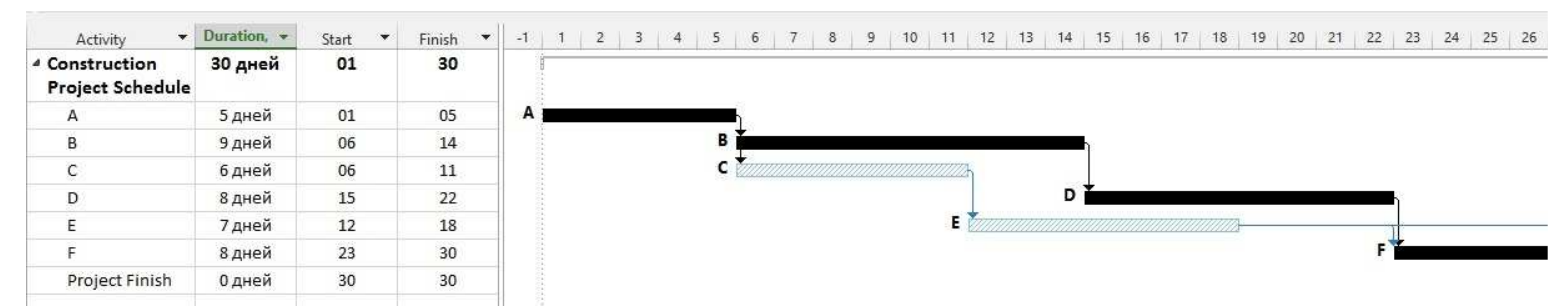

Figure 1. Project schedule with baseline duration of project activities

Critical activities $A, B, D$ and $F$ are indicated on the diagram by darkening. They shape the critical path of 30 days, which determines the total duration of the project taken as a target duration $T_{\text {tar. }}$.

Duration of individual activities of the project can be defined in accordance with the existing method by selecting efficient number and quality of teams, choice of the most suitable vehicles and equipment, the most effective work methods and etc. As a rule, decisions on duration of construction and installation works are specified in Method Statements (Russian abbreviation - PPR). The most efficient durations are characterized by the minimum cost.

At the same time individual activities of the project can be accelerated. Even before the start of the project it is possible to find margins for shortening duration of works (e.g. with the more powerful equipment, usage of materials with different characteristics etc.) and determine the value of minimum achievable durations for each activity. In addition, it is necessary to find a possibility to optimize the links in order to find the earliest possible start for subsequent activities.

Reduction of works duration nearly always leads to cost increase. However, the article considers the issues of project timely completion, so let us assume that the project management is ready to increase the project budget in order to prevent the failure to meet the Project deadlines.

Note the minimum possible activities' durations $t_{\min }$ compared to the baseline durations tbs for the example under consideration in Table 1.

Table 1. Baseline and minimum possible duration of project activities

\begin{tabular}{|c|c|c|}
\hline Activities & $\begin{array}{c}\text { Baseline Duration, } \\
t_{\text {bsl }}, \text { days }\end{array}$ & $\begin{array}{c}\text { Minimum possible duration, } \\
t_{\text {min }} \text {, days }\end{array}$ \\
\hline A & 5 & 3 \\
\hline B & 9 & 5 \\
\hline C & 6 & 4 \\
\hline D & 8 & 6 \\
\hline E & 7 & 8 \\
\hline F & 8 & 8 \\
\hline
\end{tabular}

There is also a condition that in the example considered herein there is a possibility to accelerate the project combining activities. E.g. it is possible to start activity $B$ two days before completeing activity $A$, and there is also a possibility to start activity $D$ a day before activity $B$ finishes.

Thus, in case of the maximum project acceleration, the duration of the critical path will be $3-2+8-1+4+8=20$ days.

As a result, at the moment when the baseline plan is prepared it is necessary to approve not only the baseline dates of activities of the project but also their minimum possible durations which gives big advantages in Project Risk Management, viz. transition to "accelerate mode" of project implementation in case critical deviations from the baseline approved appear.

After Project Baseline dates are approved and start of the project the tracking procedure is initiated. Picture the $10^{\text {th }}$ day of the Project implementation. During the actual data collection procedure, it has been found that the actual duration of activity $A$ is 10 days versus 5 days of Baseline duration. An increase in the duration of activity $\mathrm{A}$ has resulted in failure to start other subsequent activities on time, specifically, activities $B$ and $D$ can start on $11^{\text {th }}$ day instead of $6^{\text {th }}$.

Having analyzed the data we can get a quality evaluation of construction project schedule performance status, namely "The Project is being delayed" and the quantity value only for A activity "the value of delay is 5 days". Quantity value of strategic aim possibility to achieve - timely project completion can be calculated with the formula (1). In our case the variance from the project completion date as of the report date equal to $10^{\text {th }}$ day $\operatorname{TV}(t=10)=-5$ days. Coincidence of the $A$ activity date deviation value with Bovteev S.V., Kanyukova S.V. Development of methodology for time management of construction projects Magazine of Civil Engineering. 2016. No. 2. Pp. 102-112. doi: 10.5862/MCE.62.10 
the Project deviation value happened due to the fact that $A$ activity is critical and, thus, its duration increase resulted in overall project duration increase.

However, the existing methods cannot evaluate possibility (or impossibility) of meeting the project deadline. If the project is delayed at the moment that the project manager shall realize that there is a possibility to eliminate delay within remaining time and when approved, what exactly shall be undertaken if there are several options, it is necessary to understand the most efficient, according to the integral criteria of cost and credibility.

Herein, for our example, if the remaining part of the project is performed within the base parameters there is required $9+8+8=25$ days more to complete the project, hence, the project will be completed on the $35^{\text {th }}$ day, or 5 days later than the target date. However, provided the project is accelerated by shortening the duration of all activities to the minimum durations possible (according to Table 1), then the remaining part of the project will be performed within $8+4-1+8=19$ days. In this case, the project will be completed within 29 days, which is even earlier than the target date.

Let us suppose that activities $B$ and $D$ started on day 11 . For works in progress it is necessary to forecast their expected finish date. Suppose work B finishes on day 19. In this case, the expected total duration of the project will be no less than 30 days and provided maximum acceleration undertaken; the project can be completed on time.

Let the following tracking has revealed upon actual data collection on day 12 that B activity finish date will be on day 20 . In this case even maximum acceleration will not provide project completion earlier than on day 31 .

The aforementioned example shows the well-known fact that shall activities durations increase gradually (or start dates delayed) the estimated overall duration of the project will increase. Once it turns out the negative value of TV cannot be compensated with the remaining activities acceleration. This moment occurrence is called the Point of No Return and it guaranteed leads to Project Failure.

Specifically for our example, the Point of No Return occurs, as seen from our scales, on day 11.

Since the main goal of project time management, as stated above, is to provide timely execution of the project, it is possible to paraphrase the given statement: the main goal of project time management is to prevent the project to cross over the Point of No Return. Thus, when the project condition is close to the Point of no Return, the project schedule adjustment system shall be initiated. It is worth to mention that the variance between the approved and minimum possible durations of the project plays the role of a safety margin of time which is not recommended to be used at once, it shall be stretched for the overall duration of the project implementation. Thus, the project manager will get an effective tool of time management which can prevent the project catastrophe.

\section{Methods and results}

It is well seen from the example considered above that for the project control purposes it is important for the project to have the "margin of safety". Likewise, during structural calculations it is necessary to indicate the safety factor as a proportion of the maximum load which the structural element can bear. For the project management purposes let us introduce a coefficient of safety margin on duration $K_{s}$ equal to proportion of estimated duration of the critical path to the minimum possible duration of the critical path.

$$
K_{s}=\frac{T_{b s l n}}{T_{\min }}
$$

where $T_{b s / n}$ - baseline (estimated) duration of the critical path;

$T_{\min }$ - minimum possible duration of the critical path;

The more the safety margin coefficient value - the lower the project deadline failure risk.

In our case, the safety margin coefficient is approximately $30 / 20=1,5$.

Thus, it is necessary to suggest the methodology which assures to prevent possible approach of the critical values, and the safety margin shall be equally allocated along the project duration.

Consider two Boolean (logic) functions from time of the project which can take the value one (true) or zero (false).

First function - the function of timeliness of project completion $F_{\text {timely }}(t)$. If at the moment $t T V \geq 0$, then $F_{\text {timely }}(t)=1$, if $T V<0$, then $F_{\text {timely }}(t)=0$ (Figure 2)

Second function - the function of possibility to provide timely completion of the project $F_{\text {pssble timely }}(t)$. If at the moment $t$ there is a possibility to provide timely completion of the project (even if the project is behind the schedule), then $F_{\text {timely }}(t)=1$, if there is no such possibility, then $F_{\text {timely }}(t)=0$. The key element of this function is the condition that if it equals zero, it cannot come back to one in future (Figure 3).

Бовтеев С.В., Канюкова С.В. Развитие методики контроля сроков инвестиционно-строительного проекта // Инженерно-строительный журнал. 2016. №2(62). С. 102-112. 


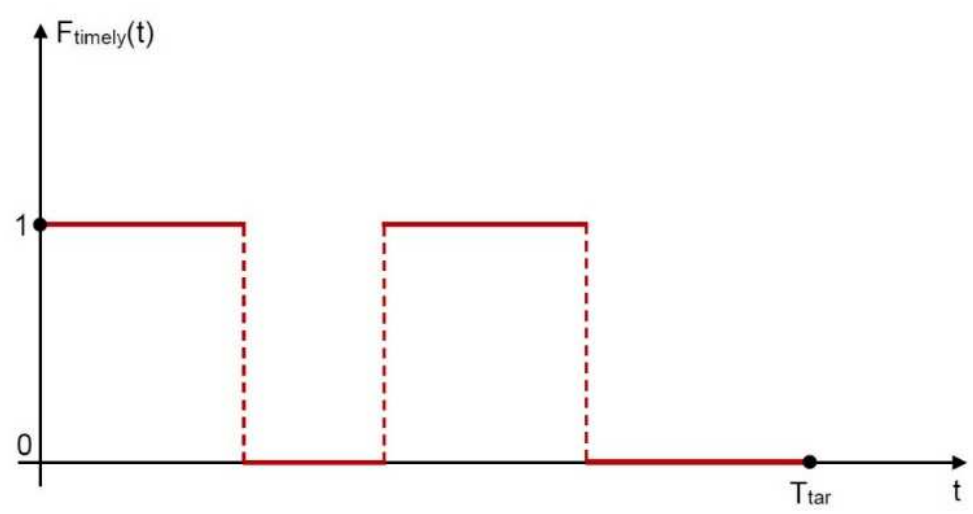

Figure 2. Function of the timeliness of project completion

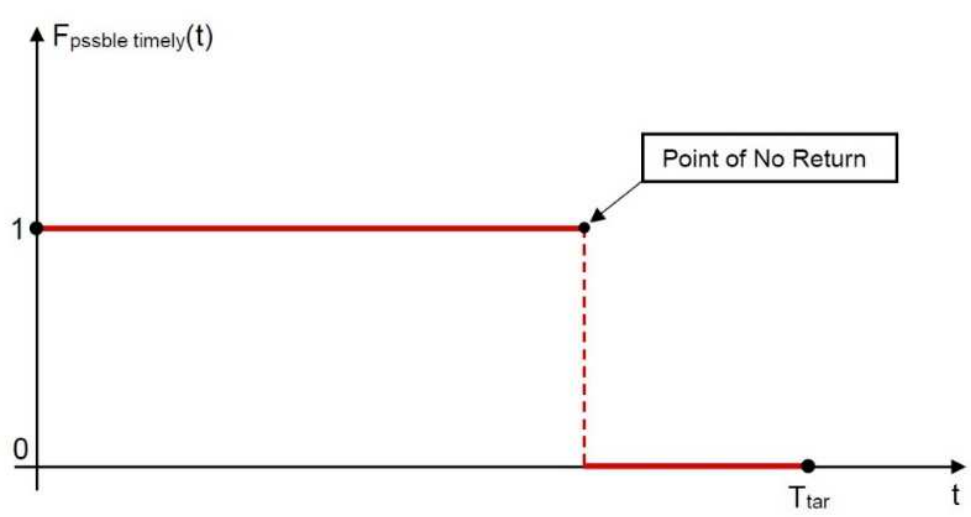

Figure 3. Function of possibility to provide timely project completion

It is obvious that the function of possibility to provide of timely project completion can equal zero when the function of timeliness of project completion is zero since if the forecast duration of the project at the moment $t$ does not exceed the approved one, then it is obvious that the project can be completed on time. On the other hand, if the function of possibility of timely project completion equals zero, then the function of timeliness of project completion is also zero and cannot be brought back to the value one.

Moment $t$, when the function of possibility of timely project completion change occur, it is possible to call the Point of No Return. This moment after which any minimum delay of a critical task or increase in duration of a critical task to any minimum value will surely lead to a failure in the project execution deadline.

It is obvious that the project manager shall be informed on approach of the Point of No Return. However, if the Point of No Return occurs at the start of the project, the project manager will have no safety margin and any minor failure will result in overall project deadline failure.

It is necessary to have a system of indication of project performance status, which can provide the occurrence of the Point of No Return under the worst conditions not earlier than the minimum possible value before the planned finish of the project.

Partially this task is solved in articles [6, 8], where one of the authors of the present article suggests the methodology of construction project time management aimed to prevent the project catastrophe and provide timely project completion. The methods are based on permanent tracking of two relative Indices: Schedule Timeliness Index (or indicator) - STI and Schedule Progress Index (or indicator) - SPI.

STI is a proportion of absolute deviation from the project completion date as of the status date to the remaining time until the approved finish date of the project:

$$
S T I(t)=\frac{T V}{\left(T_{t a r}-t_{s t}\right)}
$$

where $t_{s t}-$ status date.

Bovteev S.V., Kanyukova S.V. Development of methodology for time management of construction projects Magazine of Civil Engineering. 2016. No. 2. Pp. 102-112. doi: 10.5862/MCE.62.10 
The less time remains until the Project finishes the more attention shall be paid to the project date deviation value. Schedule Timeliness Index due to its relative nature makes it possible to register remaining time value and, thus, to recognize the extent of influence of the current deviation upon the project results.

SPI is the function of proportion between actually completed scope of works to the scope which shall be made until the status date with regard to the time left until the project completion. SPI is calculated with the formula:

$$
S P I(t)=\frac{\frac{N_{\text {complete }}}{N_{\text {plan }}}-1}{\left(T_{\text {tar }}-t_{\text {st }}\right)} \times T_{\text {tar }}
$$

where $N_{\text {complete }}$ - scope of completed work as of the status date;

$N_{\text {plan }}$ - scope of work to be completed as of the status date.

In study [28] STI is suggested as the fundamental, while SPI is supplementary. In any case, for the purposes of project time control it is necessary to define the critical borders of the Indices which can lead to project status change. The project can be located in one of the zones, according to the project probability, to be completed on time (Table 2). If the project shifts from the bright green to the yellow zone - the remaining project schedule shall be reviewed, and the measures shall be taken in order to accelerate the project. If the project shifts from the yellow to the red zone, it is considered that the project has reached the Point of No Return and has failed.

Table 2. Critical index boundary values

\begin{tabular}{|l|l|}
\hline Project zones & Index value \\
\hline Green & Above zero \\
\hline Bright green & In the range from 0 to $L_{1}$ \\
\hline Yellow & In the range from $L_{1}$ to $L_{2}$ \\
\hline Red & Below $L_{2}$ \\
\hline
\end{tabular}

Though studies [6, 8] do not deal with the issue of $L_{1}$ $L_{2}$ Indices' value critical borders estimation methods, it is mentioned that critical values of these Indices depend directly on the "margin" size stored during schedule estimations.

Let us balance the notions of Indices' value critical borders and the duration safety margin coefficient $K_{s}$ suggested in this article. This safety margin coefficient demonstrates calendar plan safety, the higher the less tense our project critical path is from the point of view of its reserves.

In our example, for instance, the safety margin is 1,5 or $50 \%$. Which means that exceeding activities duration for more that in 1,5 times shall lead to failure to complete the project on time, but if the activities durations increase in less amounts - there is a possibility to catch up with the project schedule. However, the problem here is that each critical activity is defined by its own limits of compression, thus, lineal dependency in our case can only be a very rough approximation.

Let us continue this case study. Shall we draw up several dependencies for the aforementioned period $t=0$ to $t=12$ where time of the project is the main parameter, namely:

- $F_{r}(t)$ - lineal decreasing function of the remaining project duration;

- $\mathrm{F}_{\mathrm{v} 1}(\mathrm{t})$ - non-lineal decreasing function defining maximum possible value of project dates deviation based on analogous calculation performed every day t of project implementation (i.e. for each day, we calculate the minimum amount of time for possible project delay and it can be compensated by project activities acceleration);

- $\mathrm{F}_{\mathrm{v} 2}(\mathrm{t})$ - lineal decreasing function defining maximum possible value of project dates deviation based on project safety factor equal 1,5 . The function is determined by the difference between the remaining project time and the margin volume "absorbed" for the project duration. Thus, at the project start $\mathrm{F}\left(\mathrm{t}_{0}\right)=30-30 / 1,5=10$ days, in the middle $\mathrm{F}(\mathrm{t}=30 / 2=15)=10 / 5=5$ days etc.;

- $\mathrm{TV}_{1}(\mathrm{t})$ - function of project date absolute deviation estimated as of project implementation fact, (data as of 10,11 and 12 day - see example above, data as of 1 until 9 days of the project are taken as an example);

- $\mathrm{TV}_{2}(\mathrm{t})$ - function of project date absolute deviation estimated according to hypothesis that actual duration of each critical activity and actual extension of each critical link is increased compared to the plan by project safety factor value equal to 1,5 ;

- $\mathrm{STI}_{1}$ - Schedule Completion Index, calculated based on the project deviation value $\mathrm{TV}_{1}$;

Бовтеев С.В., Канюкова С.В. Развитие методики контроля сроков инвестиционно-строительного проекта // Инженерно-строительный журнал. 2016. №2(62). С. 102-112. 
- $\mathrm{STI}_{2}$ - Schedule Completion Index, estimated based on the project deviation value $\mathrm{TV}_{2}$.

The results are given in Table 3 below.

Table 3. Project time parameters

\begin{tabular}{|c|c|c|c|c|c|c|c|}
\hline $\mathbf{t}$, days & $\mathbf{F}_{\mathbf{r}}(\mathbf{t}), \mathbf{d a y s}$ & $\mathbf{T V}_{\mathbf{1}}(\mathbf{t}), \mathbf{d a y s}$ & $\mathbf{T V}_{\mathbf{2}}(\mathbf{t})$, days & $\mathbf{F}_{\mathbf{v} 1}(\mathbf{t})$, days & $\mathbf{F}_{\mathbf{v} 2}(\mathbf{t})$, days & $\mathbf{S T I}_{\mathbf{1}}(\mathbf{t})$ & $\mathbf{S T I}_{\mathbf{2}}(\mathbf{t})$ \\
\hline 0 & 30 & 0 & 0 & -10 & -10.0 & 0.000 & 0.000 \\
\hline 1 & 29 & -0.5 & -0.5 & -9.2 & -9.7 & -0.017 & -0.017 \\
\hline 2 & 28 & -1 & -1 & -8.6 & -9.3 & -0.036 & -0.036 \\
\hline 3 & 27 & -1 & -1.5 & -8 & -9.0 & -0.037 & -0.056 \\
\hline 4 & 26 & -2 & -2 & -7 & -8.7 & -0.077 & -0.077 \\
\hline 5 & 25 & -3 & -2.5 & -6 & -8.3 & -0.120 & -0.100 \\
\hline 6 & 24 & -3 & -3 & -5.89 & -8.0 & -0.125 & -0.125 \\
\hline 7 & 23 & -3 & -3.5 & -5.78 & -7.7 & -0.130 & -0.152 \\
\hline 8 & 22 & -4 & -4 & -5.67 & -7.3 & -0.182 & -0.182 \\
\hline 9 & 21 & -4 & -4.5 & -5.56 & -7.0 & -0.190 & -0.214 \\
\hline 10 & 20 & -5 & -5 & -5.45 & -6.7 & -0.250 & -0.250 \\
\hline 11 & 19 & -5 & -5.5 & -5.34 & -6.3 & -0.263 & -0.289 \\
\hline 12 & 18 & -6 & -6 & -5.23 & -6.0 & -0.333 & -0.333 \\
\hline
\end{tabular}

The project Point of No Return studied in this article as an example occurred on day 12. This is the moment of time when, according to Table 3, $\operatorname{TV}_{1}(\mathrm{t})$ crossed line $F_{\mathrm{v} 1}(\mathrm{t})$ (Figure 4). At the same moment of time function $\mathrm{TV}_{2}(\mathrm{t})$ equaled $\mathrm{F}_{\mathrm{v} 2}(\mathrm{t})$ function value (Figure 5 ).

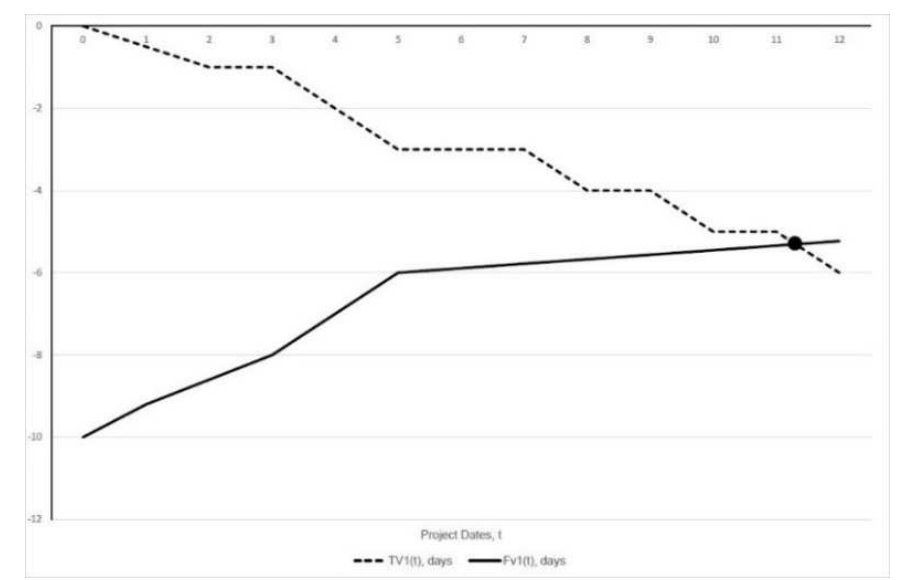

Figure 4. Functions $\mathrm{TV}_{1}(t)$ and $F_{\mathrm{v} 1}(t)$

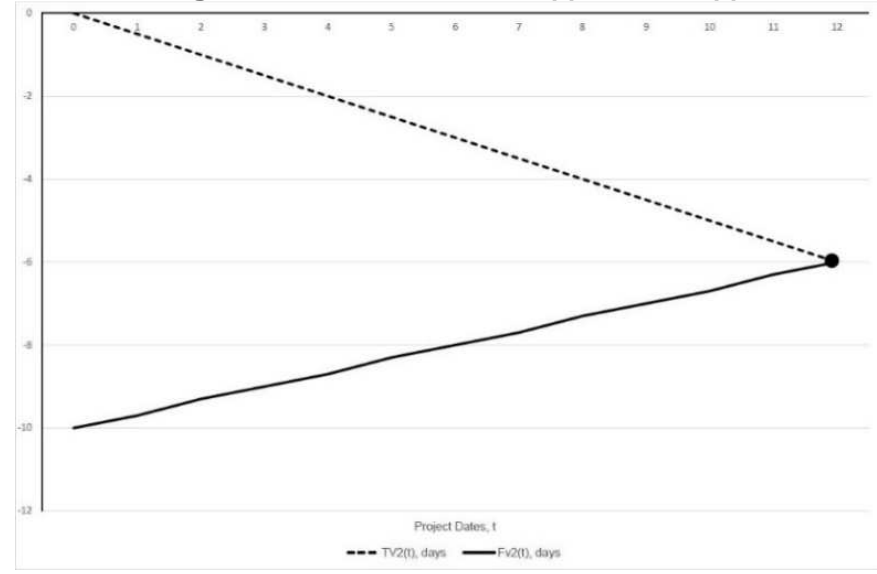

Figure 5. Functions $\mathrm{TV}_{2}(t)$ and $\mathrm{F}_{\mathrm{v} 2}(\mathrm{t})$

Note that provided that all these critical activities have different reserves for their acceleration, and provided various probabilities (or improbabilities) of timing advance values occurrence of shifting over critical links functions $F_{v 1}(t)$ and $F_{v 2}(t)$ do not generally coincide. However, it is quite difficult to calculate the value of $F_{v 1}(t)$ analytically, that is why in most cases for defining deviation critical value TV $(t)$ it is enough to use lineal function $\mathrm{F}_{\mathrm{v} 2}(\mathrm{t})$. It is recommended to use an equalizing margin coefficient which introduces the Bovteev S.V., Kanyukova S.V. Development of methodology for time management of construction projects Magazine of Civil Engineering. 2016. No. 2. Pp. 102-112. doi: 10.5862/MCE.62.10 
deviation value of functions $F_{v 1}(t)$ and $F_{v 2}(t)$, in particular, in our case the variance between these two functions value is up to $39 \%$.

Common sense of this discourse is to demonstrate the STI critical value occurrence result in project shift from the yellow zone to the red one (e.i. the Point of No Return arrives).

It is suggested to calculate the critical value of Index $L_{2}$ borders according to the following connection:

$$
L_{2}=1-\frac{1}{K_{s}}
$$

In the same way a decreasing coefficient can be introduced accounting for the range of lineal function $F_{v 2}(t)$ deviation value and non-lineal function $F_{v 1}(t)$. However, this article does not aim at studying this coefficient value calculation.

In any case, value $L_{2}$ cannot exceed the value calculated with formula (2).

The border of shifting the project from bright green to the yellow zone $-L_{1}$, the recommended value is half of $\mathrm{L}_{2}$.

\section{Discussion}

The principles of construction project time control studied in this article continue the research of some authors aimed at creation an effective methodology to assure construction project timely completion.

The drawback of previous studies was absence of understanding how to establish the activities timeliness indicators' borders (as the main indicator of activities date control and project timeliness assurance) when the project status shifts from bright-green to the yellow zone and when the project status shifts from the yellow zone to the red one. The shift from yellow to the red zone indicates arrival of the Point of No Return and further project progression will inevitably lead to project catastrophe, thus, correct definition of the border value $L_{2}$ is of the outmost importance.

Herein there given some recommendations on feasible calculation of $L_{2}$ critical value while $L_{1}$ value calculation can be proportional to $\mathrm{L}_{2}$.

The given methodology is being implemented in different users frameworks, macro's and presentation settings (layouts) in Microsoft Project 2016 и Oracle Primavera P6 software spheres, and can be used in construction projects management, especially of such projects where completion timeliness has critical nature and is the key success factor.

\section{Conclusion}

Based on the findings of the present study the following conclusions can be made:

1. The main aim of project schedule control is to assure timely project completion as well as timely completion of project key milestones. The main parameter for the purposes of project schedule control is to forecast the project completion date $T_{\text {for }}$ from target date of $T_{\text {tar, }}$ so called Time Variance (TV). TV indicator is a function of project time $t$, when TV(t) value can become negative as the project unfolds, however, only within the extent of compensation with acceleration of remaining activities duration.

2. For each project activity the minimum possible durations can be preliminary defined (before baseline schedule approval) $t_{\text {min,i, }}$ which can be reach as well with, if necessary, by means of work cost increase $\mathrm{c}_{\mathrm{i}}$. Also, it is possible to calculate maximum possible critical links advance values which can be reached in order to accelerate the activities schedule. It makes it possible to know the minimum possible duration of the remaining works at any moment of project time. If the negative value of $T V(t)$ at any point of time cannot be compensated with the maximum possible acceleration of all remaining activities, it is possible to state that at the moment the Point of No Return arrives and it will inevitably lead to the Project failure.

3. Schedule Timeliness Index is a relative indicator that allows estimating the project status upon the criteria of its timeliness at any moment of time t. The problem of defining the critical values of project shift from yellow to the red zone $\mathrm{L}_{2}$ can be solved by the means of project safety margin coefficient $\mathrm{K}_{s}$, which is a relation of approved project duration to minimum possible. It is suggested to calculate the project status shift from the yellow to the red zone, which is considered to be the Point of No Return, according to connection (6), including correction herewith to irregular nature of connection between the minimum duration and approved duration of different types of project activities. $L_{1}$ value is suggested to be equal to $L_{1}=0,5 L_{2}$. 


\section{Литература}

1. Абдуллаев Г.И. Влияние организационнотехнологических факторов на эфффективность управления строительством сооружений // Инженерностроительный журнал. 2011. № 2(20). С. 52-54.

2. Azarova I. An analysis of life cycle of projects in housing sector. Eastern-European Journal of Enterprise Technologies. 2015. Vol. 4. No. 1. Pp. 2-10.

3. Азарова И.Б. Основные аспекты ценностноориентированного управления инвестиционностроительными жилищными проектами // Инженерностроительный журнал. 2015. №7(59). С. 18-29.

4. Боровских О.Н. Особенности построения системы управления проектами в проектных организациях // Российское предпринимательство. 2014. №1 (247). С. 14-22.

5. Чулгаева О.В., Чулгаева В.С. Подготовка бизнес-плана инвестиционно-строительного проекта на основе экономико-математических моделей // Инженерностроительный журнал. 2009. №3. С. 61-64.

6. Ватин Н. И., Колосова Н.Б., Бердюгин И.А. Эфффективность применения систем автоматического управления (САУ) AccuGrade в строительстве // Строительство уникальных зданий и сооружений. 2013. № 4 (9). C. 30-35.

7. Ковалев В. В. Методы оценки инвестиционных проектов. Издательство: Финансы и статистика, 2000. $144 \mathrm{c}$.

8. Заренков В.А. Управление проектами. М.: АСВ. 2010. $312 \mathrm{c}$.

9. Werkl M., Heck D. Coping with incompleteness: An approach using time and production related compensation. 6th International Structural Engineering and Construction Conference: Modern Methods and Advances in Structural Engineering and Construction. 2011. Pp. 279-284.

10. Construction Extension to the PMBOK Guide. 3th edition. 2th Ed. Project Management Institute. Newtown Square. PA. 2007. $196 \mathrm{p}$.

11. De Marco A. Project Management for Facility Constructions. A Guide for Engineers and Architects. Springer-Verlag Berlin Heidelberg. 2011. 197 p.

12. Мазур И.И. Управление инвестиционностроительными проектами: международный подход Construction project management: international approach: руководство. 2-е изд., перераб. М.: Омега-Л, 2010. 736

13. Р2М: Руководство по управлению инновационными проектами и программами организаций. К.: Новый друк. 2010. 160 c.

14. Project Management Body of Knowledge. Guide 5th Edition. Project Management Institute. Newtown Square. PA. 2013. 506 p.

15. Чатсрилд К., Джонсон Т. Microsoft Project 2013. Русская версия. М.: ЭКОМ Паблишерз, 2013. 672 с.

16. Schlagbauer D., Heck D. Change in output performance due to prolonged work. 7th International Structural Engineering and Construction Conference: New Developments in Structural Engineering and Construction. 2013. Pp. 1375-1380.

17. Larson E.W., Gray C.F. Project Management: The Managerial Process. McGraw Hill. 2011. 608 p.

18. Practice Standard for Scheduling. Guide 2th Edition. Project Management Institute. Newtown Square. PA. 2011. $113 p$

19. Mubarak S. Construction Project Scheduling and Control. Second Edition. New Jersey. Hoboken: John Wiley \& Sons, Inc. 2010. 479 p.

20. Walker A. Project management in construction. Guide 4th Edition. Oxford: Blackwell Science. 2002. 289 p.

21. Goldratt Eliyahu. M. Critical Chain. The North River Press Publishing Corp. NY. 1997. 246 p.

22. Котовская М.А. Особенности теории ограничений систем Голдратта и метода критической цепи в области календарного планирования строительных

\section{References}

1. Abdullayev G.I. Vliyaniye organizatsionnotekhnologicheskikh faktorov na effektivnost upravleniya stroitelstvom sooruzheniy [The influence of organizational and technological factors on management efficiency the construction of buildings]. Magazine of Civil Engineering. 2011. No. 2(20). Pp. 52-54. (rus)

2. Azarova I. An analysis of life cycle of projects in housing sector. Eastern-European Journal of Enterprise Technologies. 2015. Vol. 4. No. 1. Pp. 2-10.

3. Azarova I.B. Osnovnyye aspekty tsennostnooriyentirovannogo upravleniya investitsionno-stroitelnymi zhilishchnymi proyektami [The main aspects of the valueoriented management of investment and construction housing projects]. Magazine of Civil Engineering. 2015. No. 7(59). Pp. 18-29. (rus)

4. Borovskih O. N. Osobennosti postroeniya sistemy upravleniya proektami $v$ proektnykh organizatsiyakh [Features of project management system establishment in design organizations]. The Russian journal of entrepreneurship. 2014. No. 1(247). Pp. 14-22. (rus)

5. Chulgayeva O.V., Chulgayeva V.S. Podgotovka biznesplana investitsionno-stroitelnogo proyekta na osnove ekonomiko-matematicheskikh modeley [Preparation of the business plan of investment project on the basis of economic-mathematical models]. Magazine of Civil Engineering. 2009. No. 3. Pp. 61-64. (rus)

6. Vatin N. I., Kolosova N.B., Berdyugin I.A. Effektivnost primeneniya sistem avtomaticheskogo upravleniya (SAU) AccuGrade v stroitelstve [Efficiency of use of systems of automatic control of AccuGrade in construction]. Construction of Unique Buildings and Structures. 2013. No. 4 (9). Pp. 30-35. (rus)

7. Kovalev V. V. Metody otsenki investitsionnykh proyektov [Methods of evaluation of investment projects]. Publisher: Finance and statistics. 2000. 144 p. (rus)

8. Zarenkov V.A. Upravlenie proektami. [Project Management]. Moscow. ASV. 2010. 312 p. (rus)

9. Werkl M., Heck D. Coping with incompleteness: An approach using time and production related compensation. 6th International Structural Engineering and Construction Conference: Modern Methods and Advances in Structural Engineering and Construction. 2011. Pp. 279-284.

10. Construction Extension to the PMBOK Guide. 3th edition. 2th Ed. Project Management Institute. Newtown Square. PA. 2007. $196 \mathrm{p}$

11. De Marco A. Project Management for Facility Constructions. A Guide for Engineers and Architects. Springer-Verlag Berlin Heidelberg. 2011. 197 p.

12. Mazur I.I. et al. Upravlenie investitsionno-stroitelnyimi proektami: mezhunarodnyiy podhod [Construction project management: international approach]. Moscow. Omega-L. 2010. 736 pp. (rus)

13. P2M: Rukovodstvo po upravleniu innovacionnymi proyectami I programmami organizaciy [Guidelines for the management of innovative projects and programs]. Kiev. Novyiy druk. 2010. 160 p. (rus)

14. Project Management Body of Knowledge. Guide 5th Edition. Project Management Institute. Newtown Square. PA. 2013. $506 \mathrm{p}$.

15. Chatfild K., Dzhonson T. Microsoft Project 2013. Russian version. Moscow: EKOM Pablisherz, 2013. 672 p.(rus)

16. Schlagbauer D., Heck D. Change in output performance due to prolonged work. 7th International Structural Engineering and Construction Conference: New Developments in Structural Engineering and Construction. 2013. Pp. 1375-1380.

17. Larson E.W., Gray C.F. Project Management: The Managerial Process. McGraw Hill. 2011. 608 p.

18. Practice Standard for Scheduling. Guide 2th Edition. Project Management Institute. Newtown Square. PA. 2011. $113 p$

Bovteev S.V., Kanyukova S.V. Development of methodology for time management of construction projects Magazine of Civil Engineering. 2016. No. 2. Pp. 102-112. doi: 10.5862/MCE.62.10 
проектов // Современные проблемы науки и образования: научный журнал. 2014. № 4. С. 234-235.

23. Линч Л. Вовремя и в рамках бюджета: Управление проектами по методу критической цепи. М.: Альпина Паблишерз, 2015. 354 с.

24. Хомутинникова К.С. Критерии оценки методов контроля, используемых при управлении строительным проектом // Управление проектами и программами. 2009. №4. С. 312-323.

25. Lipke W. Earned schedule contribution to project management. PM World Journal. 2012. Vol. 1. No. 2. Pp. 6-13.

26. Practice Standard for Earned Value Management. Guide 2th Edition. Project Management Institute. Newtown Square. PA. 2011. 54 p.

27. Bovteev S., Petrochenko M. Method "Earned Value Management" for Timescale Controlling in Construction Projects. Applied Mechanics and Materials. 2015. Vol. 725-726 "Innovative Technologies in Development of Construction Industry". Pp. 1025-1030.

28. Бовтеев С.В., Терентьева Е.В. Управление сроками строительного проекта // Управление проектами и программами. 2014. № 2 (38). С. 158-173.
19. Mubarak S. Construction Project Scheduling and Control. Second Edition. New Jersey. Hoboken: John Wiley \& Sons, Inc. 2010. 479 p

20. Walker A. Project management in construction. Guide 4th Edition. Oxford: Blackwell Science. 2002. 289 p.

21. Goldratt Eliyahu. M. Critical Chain. The North River Press Publishing Corp. NY. 1997. 246 p.

22. Kotovskaya M.A. Osobennosti teorii ogranicheniy sistem Goldratta i metoda kriticheskoy tsepi v oblasti kalendarnogo planirovaniya stroitelnykh proyektov [Specific features of goldratt\&acutes theory of constraints and critical chain project management in the scheduling of construction projects]. Modern problems of science and education. 2014. No. 4. Pp. 234-235. (rus)

23. Linch L. Vovremya i v ramkakh byudzheta: Upravleniye proyektami po metodu kriticheskoy tsepi [On time and under budget: a project Management method critical chain]. Moscow: Alpina Pablisherz. 2010. 354 p. (rus)

24. Khomutinnikova K.S. Kriterii otsenki metodov kontrolya, ispolzuyemykh pri upravlenii stroitelnym proyektom [Evaluation criteria methods of control used in the management of construction project]. Upravleniye proyektami i programmami. 2009. No. 4. Pp. 312-323. (rus)

25. Lipke W. Earned schedule contribution to project management. PM World Journal. 2012. Vol. 1. No. 2. Pp. 6-13.

26. Practice Standard for Earned Value Management. Guide 2th Edition. Project Management Institute. Newtown Square. PA. 2011.54 p.

27. Bovteev S., Petrochenko M. Method "Earned Value Management" for Timescale Controlling in Construction Projects. Applied Mechanics and Materials. 2015. Vol. 725-726 "Innovative Technologies in Development of Construction Industry". Pp. 1025-1030.

28. Bovteyev S.V., Terentyeva Ye.V. Upravleniye srokami stroitelnogo proyekta [Time management of a construction project]. Upravleniye proyektami i programmami. 2014. No. 2 (38). Pp. 158-173. (rus)

\author{
Сергей Владимирович Бовтеев, \\ +7(921)7870346; эл. почта: \\ sergeibovteev@gmail.com \\ Светлана Валерьевна Канюкова, \\ +7(952)3839947; эл. почта: \\ sv.v.kan@mail.ru
} \\ Sergei Bovteev, +7(921)7870346; sergeibovteev@gmail.com \\ Svetlana Kanyukova, +7(952)3839947; sv.v.kan@mail.ru}

(C) Bovteev S.V., Kanyukova S.V., 2016

Бовтеев С.В., Канюкова С.В. Развитие методики контроля сроков инвестиционно-строительного проекта // Инженерно-строительный журнал. 2016. №2(62). С. 102-112. 